\title{
Permasalahan Belajar Siswa dan Strategi Sekolah Selama Pembelajaran Daring di Masa Pandemi Covid-19
}

\author{
Student Learning Problems and School Strategies During the Covid-19 Pandemic Online \\ Learning
}

\author{
Arif Jauhari $^{1}$, Priyono ${ }^{2}$, Cueva Syunyata R. Jauhari ${ }^{3}$ \\ ${ }^{1,2}$ Fakultas Geografi Universitas Muhammadiyah Surakarta, \\ ${ }^{3}$ SMA Muhammadiyah Al Kautsar Program Khusus Kartasura
}

\section{ARTICLE INFO}

Article history:

DOI:

10.30595/pssh.v1i.69

Submitted:

April 12, 2021

Accepted:

June 10, 2021

Published:

June 14, 2021

\section{Keywords:}

pandemic, Covid-19, education,

ABSTRACT

It has been more than a year of the Covid-19 pandemic, after WHO officially announced it on March 11, 2020. This pandemic has had a tremendous impact on all aspects of life, including education, where education must be carried out online. This drastic change will certainly encounter many obstacles. This study aims to determine the problems of online learning due to the Covid-19 pandemic faced by students of SMA Muhammadiyah Al Kautsar Kartasura Program Khusus and the strategies implemented by the school. This research method is a qualitative case study. Data collection techniques are observation, analysis and unstructured interviews. Observations to find the keywords of student learning problems in grade 10 science and 11 science students. Analysis to trace student conversations on social media based on the observed key words. Interviews were conducted to extract information, while the sampling technique was purposive sampling. The results showed that there were three student learning problems, namely boredom, lack of understanding of the material, and the need for internet quota. The school strategy includes, firstly relating to administration and secondly relating to the implementation of learning. The administrative strategy is carried out with flexibility in paying tuition fees and contributing to institutional development. The learning strategy is a home-school collaboration as an important component in evaluating and monitoring the teaching and learning process by online.
\end{abstract} learning, strategy
This work is licensed under a Creative Commons Attribution 4.0 International License.

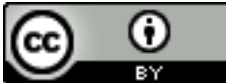

\section{Corresponding Author:}

Arif Jauhari

Fakultas Geografi Universitas Muhammadiyah Surakarta

Jl. A. Yani, Mendungan, Pabelan, Kec. Kartasura, Kabupaten Sukoharjo, Jawa Tengah 57169

Email: arifjauhari1995@gmail.com

\section{PENDAHULUAN}

Satu tahun lebih pandemi Covid-19 telah berlangsung di seluruh dunia, setelah secara resmi WHO mengumumkan pada tanggal 11 Maret 2020. Data worldometers.info menyebutkan saat ini setelah sekitar satu tahun resmi berlaku kondisi pandemi, lebih dari 126 juta penduduk dunia terkonfirmasi positif, dan lebih dari 2,7 juta orang telah meninggal akibat kasus Covid-19. Dampak pandemi terhadap semua aspek kehidupan sangat luar biasa. Bahkan Sekretaris Eksekutif I Komite Penanganan Covid-19 dan Pemulihan Ekonomi Nasional (KPCPEN) Raden Pardede mengatakan, pandemi Covid-19 membuat Indonesia menghadapi krisis terberat sejak merdeka, Indonesia seperti halnya negara-negara lain juga mengalami tekanan berat yang berdampak ke berbagai sektor, termasuk kesehatan, ekonomi, hingga sosial [1].

Dunia pendidikan tidak terlepas dari krisis ini dan berbagai dampak turunannya. Mendikbud mengatakan kondisi Pandemi Covid-19 tidak memungkinkan kegiatan belajar mengajar berlangsung secara normal, prioritas 
utama pemerintah adalah untuk mengutamakan kesehatan dan keselamatan peserta didik, pendidik, tenaga kependidikan, keluarga, dan masyarakat secara umum, serta mempertimbangkan tumbuh kembang peserta didik dan kondisi psikososial dalam upaya pemenuhan layanan pendidikan selama pandemi Covid-19 [2]. Untuk mencegah penyebaran Covid-19, sekolah-sekolah akhirnya ditutup untuk sementara, tetapi pembelajaran harus tetap dilakukan. Implementasi dari kebijakan pemerintah ini adalah pembelajaran harus dilakukan secara daring atau pembelajaran jarak jauh (PJJ). Hal ini memberikan dampak yang luar biasa bagi setiap komponen pendidikan termasuk di dalamnya pimpinan institus $i$, pengajar, karyanan, siswa dan juga orang tua siswa.

Kurikulum dapat disesuaikan dengan kebutuhan pembelajaran pada daerah dalam kondisi khusus, yaitu suatu kondisi dalam keadaan bencana yang ditetapkan oleh Pemerintah Pusat atau Pemerintah Daerah [3]. Beban kurikulum akhirnya menjadi fleksibel, tetapi pengajar juga akan mengalami kendala juga. Penguasaan teknologi kekinian, terutama pertemuan daring dan aplikasi pendidikan berbasis internet menyebabkan pengajar dan juga siswa harus banyak melakukan penyesuaian. Pembelajaran daring akan membawa problem tersendiri bagi para siswa, beberapa problem tersebut adalah kesulitan konsentrasi belajar, beratnya penugasan guru, rasa stress dan jenuh [4].

Penelitian ini bertujuan untuk mengetahui problem yang dihadapi siswa di SMA Muhammadiyah Al Kautsar Program Khusus Kartasura, Kabupaten Sukoharjo dan strategi yang dilakukan oleh sekolah sebagai solusi problem tersebut.

\section{METODE PENELITIAN}

Metode pada penelitian ini adalah studi kasus kualitatif untuk memperoleh informasi mengenai problem yang dihadapi siswa dan strategi yang dilakukan oleh sekolah untuk mengatasi problem tersebut akibat dari pandemi covid-19 terhadap proses pembelajaran. Pendekatan eksploratif digunakan untuk mencari problem dan strategi yang digunakan oleh guru dan pimpinan sekolah. Lokasi penelitian adalah SMA Muhammadiyah Al Kautsar Program Khusus Kartasura, Kabupaten Sukoharjo Provinsi Jawa Tengah. Sampel didasarkan pada kedalaman deskripsi, dengan responden yaitu 5 siswa, 3 pimpinan dan guru. Teknik pengambilan data dengan tiga alat penelitian yaitu observasi dan dokumentasi serta wawancara tak terstruktur. Observasi dilakukan melalui komunikasi pada murid kelas 10 IPA dan 11 IPA. Dokumentasi untuk menelusuri percakapan di media sosial berdasarkan kata-kata kunci hasil observasi. Wawancara dilakukan untuk penggalian informasi yang bersifat eksploratif, sedangkan teknik pengambilan sampel adalah purposive sampling. Data di analisis menggunakan analisis data kualitatif, yaitu upaya yang dilakukan peneliti untuk mengorganisasikan data, mengelompokkan menjadi satuan-satuan, mensintesis, mencari dan menemukan pola, menemukan apa yang penting, dan memutuskan apa yang dapat dilaporkan kepada orang lain [5].

\section{HASIL DAN PEMBAHASAN}

Pendidikan adalah usaha sadar dan terencana untuk mewujudkan suasana belajar dan proses pembelajaran agar peserta didik secara aktif mengembangkan potensi dirinya untuk memiliki kekuatan spiritual keagamaan, pengendalian diri, kepribadian, kecerdasan, ahklak mulia, serta keterampilan yang diperlukan dirinya, masyarakat, bangsa dan Negara [6]. Pendidikan yang dilakukan sebelum pandemi sebagian besar adalah pembelajaran secara tatap muka. Pembelajaran tatap muka memiliki berbagai kelebihan terhadap pengajar maupun peserta didik meliputi: 1) Disiplin formal yang diterapkan pada pembelajaran tatap muka dapat membentuk disiplin mental; 2) Memudahkan pemberian penguatan dengan segera; 3) Memudahkan proses penilaian oleh pengajar; 4) Menjadi wahana belajar berinteraksi terhadap peserta didik; 5) Kemampuan sosialisasi imbal balik antara pengajar, peserta didik, maupun staf di sekolah; 6) Pengajar dapat mengamati secara langsung sikap dan tingkah laku siswa dalam menerima materi [7]. Kondisi pandemi Covid-19 yang sangat cepat dalam transmisinya menyebabkan berbagai pihak dalam dunia pendidikan kelabakan dalam beraktivitas karena harus meninggalkan 'zona nyaman'-nya. Pemerintah akhirnya memutuskan untuk memberlakukan pembelajaran daring.

Pengajar dan peserta didik belum siap beraktifitas secara daring serta beberapa infrastruktur juga belum siap, terutama akses internet dan peralatan yang dibutuhkan, seperti laptop, telepon pintar bahkan peralatan multimedia dan telekonferen. Peserta didik yang sebelum pandemi mengikuti pembelajaran di kelas harus dihadapkan dengan belajar di rumah sendiri dengan situasi yang sangat berbeda. Kondisi belajar di rumah serta adanya beberapa kali libur panjang dalam pengajaran semakin menambah kebosanan siswa.

Observasi dilakukan melalui komunikasi daring, baik melalui komunikasi telepon ataupun aplikasi pembelajaran serta komunikasi guru dan wali siswa secara daring. Hasil observasi merupakan kata-kata kunci problem pembelajaran siswa dan motivasi guru serta rencana-rencana strategi. Kata-kata kunci yang muncul dalam bahasa Jawa adalah males, gak mudeng, gak paham, gak ngerti, serta kuota dan kuota habis. Kata males dalam kontek ini bukan sekedar bermalas-malasan, tetapi lebih kepada kebosanan siswa yang menyebabkan malas mengerjakan sesuatu. Gak mudeng, gak paham, gak ngerti, yakin remidi merupakan ungkapan untuk kurangnya pemahaman siswa tentang materi yang diajarkan. Kuota dan kuota habis mengartikan bahwa kuota data internet 
berbasis seluler yang hampir habis atau habis. Guru telah dan selalu memberikan motivasi ke siswa pada setiap pertemuan daring ataupun pemberian tugas dengan kata-kata semangat dan sukses.

Selain rasa bosan, pembelajaran pada masa pandemi covid-19 ini tentunya membawakan dampak pada motivasi belajar siswa yang beragam [6]. Hal ini tentunya juga berpengaruh pada pemahaman siswa terhadap materi yang diajarkan. Materi siaran "Belajar dari Rumah" di TVRI dari tingkat TK, SD, SMP serta SMA masih sangat terbatas dan belum mencukupi. Aplikasi telekonferen dan panggilan video dapat juga dimanfaatkan, konten multimedia yang lebih menarik serta kekinian mestinya dapat meningkatkan minat dan motivasi belajar dari rumah. Guru-guru pada setiap pembelajaran menyisipkan kalimat motivasi untuk menyemangati siswa dalam mengatasi kebosanan serta memotivasi untuk belajar baik pada waktu proses jam sekolah ataupun belajar mandiri di rumah.

Pembelajaran berbasis daring tentunya masih memiliki kekurangan, salah satunya adalah membutuhkan kuota internet. Tidak semua siswa, terutama siswa di SMA Muhammadiyah Al Kautsar Program Khusus Kartasura dapat mempunyai fasilitas langganan internet dari suatu provider sehingga kuota tidak terbatas. Sebagian besar masih memakai kuota internet berbasiskan layanan seluler dengan biaya yang lebih mahal.

Dokumentasi dilakukan dengan penelusuran percakapan media sosial yaitu WhatsApp (WA) dari kata-kata kunci yang didapatkan dari observasi. Percakapan ini merupakan percakapan dua pihak atau melalui kelompok atau grup dari kelas X IPA dan XI IPA. Data percakapan problem siswa disajikan pada Tabel 1.

Tabel 1. Dokumentasi Percakapan Problem Siswa SMA Muhammadiyah Al Kautsar Program Khusus Kartasura

\begin{tabular}{lccc}
\hline Kelas & Bosan & Kurang paham & Kuota internet \\
\hline Klas X IPA & $5 \mathrm{kali}$ & $7 \mathrm{kali}$ & $5 \mathrm{kali}$ \\
Klas XI IPA & $4 \mathrm{kali}$ & $13 \mathrm{kali}$ & 0 \\
\hline
\end{tabular}

Wawancara dengan siswa SMA Muhammadiyah Al Kautsar Program Khusus Kartasura dilakukan untuk menggali informasi problem yang dihadapi selama pembelajaran daring. Wawancara dilakukan tidak terstruktur dan terutama saat kerja kelompok pada kelas X IPA. Hal ini dilakukan dengan tujuan penggalian informasi yang mendalam serta responden merasa bebas dalam mengemukakan opininya. Benang merah dari wawancara dengan responden yaitu problem siswa yang dihadapi adalah kebosanan, pemahaman yang kurang dalam materi yang diajarkan, dan kebutuhan kuota internet.

Tabel 2. Wawancara Problem Siswa Kelas X IPA SMA Muhammadiyah Al Kautsar Program Khusus Kartasura

\begin{tabular}{llll}
\hline Ungkapan & Anggota & Grup & Waktu \\
\hline Kuota Terbatas & Dxxx & 6 & 03 Februari 2020 \\
Kuota Terbatas & Cxxxx & 6 & 03 Oktober 2020 \\
Kuota Terbatas & Dxxx & 6 & 03 Oktober 2020 \\
Bosen & Axxxx & 6 & 03 Oktober 2020 \\
Ga Paham & Sxxxx & 6 & 10 Oktober 2020 \\
Kuota Terbatas & Rxxxx & 6 & 24 Oktober 2020 \\
Kuota Terbatas & Dxxx & 6 & 06 November 2020 \\
\hline
\end{tabular}

Problem yang harus dihadapi guru dan siswa dalam proses pembelajaran jarak jauh melalui media daring [8], di antaranya: 1) Ketimpangan teknologi antara sekolah di kota besar dan daerah; 2) Keterbatasan kompetensi guru dalam pemanfaatan aplikasi pembelajaran; 3) Keterbatasan sumberdaya untuk pemanfaatan teknologi pendidikan seperti internet dan kuota; 4) Relasi guru-murid-orang tua dalam pembelajaran daring yang belum integral. Problem seperti pada poin 2,3 serta 4 juga terjadi di SMA Muhammadiyah Al Kautsar Program Khusus Kartasura selama sekitar satu tahun ini.

Wawancara kepada pimpinan SMA Muhammadiyah Al Kautsar Program Khusus Kartasura dilakukan untuk menggali informasi tentang strategi yang telah dan akan dilakukan untuk mengatasi problem yang dihadapi oleh siswa, yaitu: 1) Kepala sekolah mengambil kebijakan fleksibilitas pembayaran sekolah, b) Sekolah menyediakan program Sultan (konsultasi dan tanya), c) Program Pekan No PR yang kemudian diganti program Catalist Week, dan d) Fungsi guru yang lebih paham teknologi informasi internet.

Kondisi ekonomi global terpuruk, menyebabkan banyak kesulitan dalam ekonomi keluarga. Fleksibilitas dalam pembayaran sekolah meliputi biaya SPP dan cicilan sumbangan pengembangan institusi pada saat pandemi sangat perlu dilakukan. Hal ini dilakukan untuk meringankan beban keuangan keluarga wali siswa, sehingga dapat untuk memenuhi kuota internet terlebih dahulu.

Pandangan konstruktivisme merubah orientasi pembelajaran dari pembelajaran yang berpusat pada guru (teaching centered) ke pembelajaran yang berpusat pada orang yang belajar (student centered), dimana peran guru dalam pembelajaran adalah membantu siswa agar proses konstruksi konsep/materi pelajaran dapat berjalan 
dengan sendirinya sehingga apa yang dipelajari oleh siswa benar-benar dipahami dan dapat bermanfaat bagi dirinya [8]. Program Sultan merupakan aplikasi yang mengajak siswa menjadi pusat pembelajaran, tujuan utama untuk membantu siswa dalam memahami materi yang dirasa masih belum dipahami. Program ini mengacu pada keaktifan, siswa diajak aktif dalam hal pembelajaran dan dapat mengevaluasi kekurangan masing-masing dalam penguasaan materi. Pelaksanaan program Sultan pada awal tahun ajaran 2021/2022.

Kebosanan yang muncul akibat pelaksaaan pembelajaran secara daring, dilakukan dengan Pekan No PR, yaitu suatu program pembelajaran dimana dalam satu minggu pada setiap bulan tidak ada tugas ataupun pekerjaan rumah bari para siswa. Program ini dilaksanakan pertengahan semester 1 tahun ajaran 2021/2022. Awalnya berjalan efektif, tetapi kebosanan yang kembali muncul menyebabkan siswa menjadi malas untuk belajar mandiri. Hal ini ternyata cukup meresahkan orangtua, sehingga beberapa orang tua menghubungi pimpinan sekolah baik melalui pesan pribadi maupun pesan grup.

Relasi yang sebelum pandemi telah terbangun melalui pertemuan wali siswa dan guru serta program home visit menjadi tidak bisa dilakukan. Sekolah mengusulkan pertemuan daring dengan wali siswa, melalui program Korsa. Pada pertemuan ini, evaluasi dan monitoring pembalajaran dapat didiskusikan serta bobot tugas siswa dapat dievaluasi antara kedua belah pihak. Pertemuan seluruh wali siswa dilakukan untuk mencari dan berusaha menemukan solusi problem yang dihadapi siswa. Program Pekan No PR dievaluasi dan diusulkan menjadi program Catalist Week. Program ini mengajak siswa untuk aktif dalam menyusun suatu karya melalui perencanaan, pelaksanaan dan evaluasi oleh guru. Program ini telah dijalankan, dan sangat variatif karya-karya siswa meliputi bidang kuliner, penulisan, busana sampai pada bisnis usaha kecil. Program "Korsa" juga menyepakati bahwa beban tugas bertambah dan kedisiplinan siswa diwujudkan dalam presensi setiap jam pelajaran. Sebagai umpan balik, para guru meminta kepada wali siswa bahwa jam belajar harus ditaati dan juga didukung sepenuhnya serta wali siswa dapat memotivasi belajar anak-anaknya. Artinya kerjasama, relasi hubungan berjalan baik dalam proses kegiatan belajar mengajar.

Pembelajaran daring dengan memanfaatkjan berbagai aplikasi mempunyai kendala yaitu, tidak semua guru berkompeten atau menguasai. Hal termudah yang dilakukan adalah guru-guru yang paham atau berkompeten menjadi mentor bahkan operator bagi guru-guru lain yang belum menguasai aplikasi pembelajaran daring. Pengajar dan staff bergantian melaksanakan piket atau menyelesaikan tugas masing-masing. Kesempatan ini sering dimanfaatkan oleh para guru untuk melakukan pembelajaran sekaligus juga berlatih tentang penggunaan aplikasi.

Selain dengan pimpinan sekolah, wawancara juga dilakukan dengan guru. Hasil wawancara sejalan dengan kebijakan sekolah yaitu:

a. Semua guru sudah memakai aplikasi pembelajaran daring dalam menyampaikan materi yang jugadilengkapi dengan video pembelajaran.

b. Capaian minimal pembelajaran adalah siswa mengetahui manfaat materi ajar dalam kehidupan seharihari serta dapat mempraktekannya.

c. Setiap pembelajaran disisipi dengan kalimat motivasi.

Pertimbangkan transmisi Covid-19 harus menjadi pegangan, pencegahan dan mitigasi terutama berbasis komunitas lokal dapat menjadi garda depan pencegahan. Diperlukan upaya peningkatan kemampuan dan kapabilitas dari komunitas melalui Pengurangan Risiko Bencana Berbasis Komunitas atau biasa disingkat menjadi PRBBK [9]. Sekolah sebagai suatu komunitas tentunya dapat melaksanakan mitigasi Covid-19 melalui berbagai strategi. Pelaksanaan pembelajaran daring semestinya menjadi titik start dalam pembelajaran yang kreatif, inovatif dan berperan serta untuk pencegahan penularan Covid-19.

\section{KESIMPULAN}

Siswa SMA Muhammadiyah Al Kautsar Program Khusus Kartasura selama pembelajaran daring menghadapi beberapa problem meliputi kebosanan, pemahaman yang kurang dalam materi yang diajarkan, dan kebutuhan kuota internet yang selalu bertambah. Strategi secara inovatif dan kreatif serta bersifat kekinian sangat diperlukan dalam menghadapi problem pembelajaran siswa akibat pandemi Covid-19. Dua strategi dilakukan dalam pembelajaran yaitu strategi administratif dan strategi pelaksanaan pembelajaran.

\section{Acknowledgements}

Terimakasih yang sebesar-besarnya kepada berbagai pihak untuk dapat terselesaikannya penelitian ini, ucapan terima kasih kepada Pimpinan, pengajar dan staff SMA Muhammadiyah Al Kautsar Program Khusus Kartasura serta Siswa SMA Muhammadiyah Al Kautsar Program Khusus Kartasura, terutama kelas 10.

\section{DAFTAR PUSTAKA}

[1] Librianty, Andina. (2021). Dampak Pandemi Covid-19, Indonesia Hadapi Krisis Terberat. Tersedia pada: https://www.merdeka.com/uang/dampak-pandemi-covid-19-indonesia-hadapi-krisis-terberat.html. 
Diakses pada Tanggal 25 Maret 2021

[2] Pengelola Web Kemendikbud. (2020). Penyesuaian Keputusan Bersama Empat Menteri tentang Panduan Pembelajaran di Masa Pandemi COVID-19. Tersedia pada: https://www.kemdikbud.go.id/main/blog/2020/08/penyesuaian-keputusan-bersama-empat-menteritentang-panduan-pembelajaran-di-masa-pandemi-covid19. Diakses pada Tanggal 25 Maret 2021.

[3] Kemendikbud. (2020). Keputusan Menteri Pendidikan dan Kebudayaan Republik Indonesia Nomor 719/P/2020 Tentang Pedoman Pelaksanaan Kurikulum pada Satuan Pendidikan. Tersedia pada: https://www.kemdikbud.go.id/main/files/download/b132c61a5ba32c6. Diakses pada Tanggal 25 Maret 2021.

[4] Kemendikbud. (2020). Penyesuaian Kebijakan Pembelajaran di Masa Pandemi COVID-19. Presentasi. kemdikbud.go.id. Tersedia pada: https://www.kemdikbud.go.id/main/blog/2020/08/penyesuaiankeputusan-bersama-empat-menteri-tentang-panduan-pembelajaran-di-masa-pandemi-covid19. Diakses pada Tanggal 25 Maret 2021.

[5] Ulfatin, N. 2014. Metode Penelitian Kualitatif di Bidang Pendidikan: Teori dan Aplikasinya. Malang: Bayumedia.

[6] Siswadi, Gede Agus (2020). Dimensi Pendidikan Pada Masa Pandemi (Tinjauan Aliran Filsafat Rekonstruksionalisme). Dalam Covid-19: Perpektif Pendidikan, hal. 187-195. Penerbit Yayasan Kita Menulis.

[7] Sudarsana, I Ketut (2020). Pembelajaran Dalam Jaringan dan Upaya Memutus Pandemi Covid-19. Dalam Covid-19: Perpektif Pendidikan, hal. 1-9. Penerbit Yayasan Kita Menulis.

[8] Winaya, I Made Astra. (200). Pembelajaran Daring yang Efektif sebagai 'NEW NORMAL' Sekolah di tengah Pandemi Covid-19. Dalam Covid-19: Perspektif Pendidikan, hal. 173-185. Penerbit Yayasan Kita Menulis.

[9] Hadi, Suprayoga. (2020). Pengurangan Risiko Pandemik Covid-19 Secara Partisipatif: Suatu Tinjauan Ketahanan Nasional terhadap Bencana. The Indonesian Journal of Development Planning, Volume IV No. 2 - Juni 2020. 